\title{
PENANGANAN PENGUNGSI DARI LUAR NEGERI OLEH PETUGAS RUMAH DETENSI IMIGRASI DI PROVINSI SULAWESI SELATAN
}

\author{
( Treatment to International Refugees by the Officuals of \\ Immigration Detention Center in the Province of South Sulawesi)
}

\author{
Yuliana Primawardani \\ Pusat Penelitian dan Pengembangan Hak Asasi Manusia Badan Penelitian dan \\ Pengembangan Hukum dan HAM R.I. \\ Kementerian Hukum dan Hak Asasi Manusia Republik Indonesia \\ JI. HR. Rasuna Said Kav.4-5, Kuningan Jakarta Selatan 12940 \\ E-mail:ima_dephum@yahoo.com
}

\author{
Arief Rianto Kurniawan \\ Pusat Penelitian dan Pengembangan Hak Asasi Manusia Badan Penelitian dan Pengembangan \\ Hukum dan HAM R.I. \\ Kementerian Hukum dan Hak Asasi Manusia Republik Indonesia \\ JI. HR. Rasuna Said Kav.4-5, Kuningan Jakarta Selatan 12940 \\ E-mail: sandihari103@gmail.com
}

Tulisan Diterima: 11 Juli 2018; Direvisi: 20 Juli 2018;

Disetujui Diterbitkan: 23 Juli 2018

DOI: http://dx.doi.org/10.30641/kebijakan.2018.V12.179-197

\begin{abstract}
Abstrak
Penelitian ini bertujuan untuk mendapatkan deskripsi tentang Penanganan Pengungsi dari Luar Negeri sesuai dengan Peraturan Presiden No. 125 Tahun 2016 tentang Penanganan Pengungsi dari Luar Negeri, khususnya dilihat dari aspek Kelembagaan, ketatalaksanaan dan Infrastruktur. Penelitian ini menggunakan pendekatan kualitatif dan dilaksanakan di provinsi Sulawesi Selatan. Hasil Penelitian menyimpulkan bahwa Penanganan pengungsi oleh Rumah Detensi Imigrasi Makassar telah sesuai dengan Peraturan Presiden No.125 Tahun 2016, walaupun pada aspek kelembagaan dan ketatalaksanaan dan infrastruktur masih belum sesuai dengan postur tugas dan kewenangan Rumah Detensi Imigrasi. Hal ini dapat terlihat dari belum adanya perubahan dalam struktur organisasasi, belum adanya revisi Standar Operasional Prosedur yang digunakan dan keterbatasan sumber daya manusia yang ada. Begitupun dalam infrastruktur yang masih memiliki keterbatasan perangkat mobilisasi dan perangkat keamanan dalam melakukan pengawasan. Oleh karena itu perlu dilakukan penyesuaian terhadap struktur kelembagaan pada Rumah Detensi Imigrasi, menyediakan infrastruktur dan segera melakukan perbaikan terhadap standar operasional prosedur. Selain itu juga perlu adanya Unit Layanan Pengungsi di Makassar sebagai perpanjangan tangan Rumah Detensi Imigrasi dalam melakukan pengawasan mengingat lokasi Rumah Detensi Imigrasi yang berada sangat jauh dari tempat penampungan pengungsi.
\end{abstract}

Kata Kunci: Penanganan Pengungsi, Pengawasan, Rumah Detensi Imigrasi 


\begin{abstract}
This research is aimed to collect more information on Treatment of International Refugees under the President Regulation No. 125 of 2016 regarding Treatment to International Refugees, in particular when viewed from the aspects of Institution, administration and Infrastructure. This research uses qualitative approach and conducted in the Province of South Sulawesi. The result concludes that the Treatment of refugees by the Immigration Detention Center of Makassar has been in compliance with the President Regulation No. 125 of 2016, despite of non-conformities, in the aspects of institution, administration and infrastructure, to the duties and authorities of the Immigration Detention Center. This may be seedn from the absence of change to the organizational structure, no revision to the applicable Standard Operational Procedures and limited human resources. While the infrastructure has been limited in mobilization and security apparatuses in performing the supervision duties. Consequently, adjustment is required to the institutional structure of the Immigration Detention Center, by providing more infrastructure and immediately revising the Standard Operational Procedures. In addition, a Refugees Service Unit is also required to be established in Makassar as the long arms of the Immigration Detention Center in its watch in view of the location of the Immigration Detention Center which is far away from the refugees shelters.
\end{abstract}

Keywords: Treatment to Refugees, Supervision, Immigration Detention Center

\section{PENDAHULUAN}

\section{Latar Belakang}

Kehadiran "pengungsi" dan "pencari Suaka" merupakan fenomena sosial dalam hubungan internasional, yang memberikan dampak signifikan terhadap kebijakan Negera penerima. Hal tersebut juga terjadi di Indonesia yang berupaya memberikan perlindungan terhadap para pengungsi dan pencari suaka yang datang ke Indonesia. Dalam hal ini Kewajiban Negara untuk menghormati, melindungi, dan menegakkan Hak Asasi Manusia bukan hanya ditujukan kepada warga negara Indonesia saja, tetapi juga meliputi warga negara dari negara lain yang berada di wilayah Indonesia, baik mereka berada secara legal ataupun ilegal."1 Jaminan Hak Asasi Manusia (HAM) yang disebutkan didalam Pasal 2, ayat 1 Kovenan Hak Sipil Politik berlaku bagi: "semua individu yang berada di dalam wilayahnya dan berada di bawah yurisdiksinya".

Data The United Nations High Commissioner for Refugees (UNHCR) per 31 Januari 3017 menunjukkan bahwa jumlah imigran atau pengungsi yang masuk ke Indonesia sebanyak 14.425 orang, yang terdiri atas 8.039 pengungsi dan 6.386 pencari suaka. Para pengungsi tersebut menyebar ke seluruh wilayah Indonesia yaitu 2.177 orang berada di rumah detensi Imigrasi (rudenim), 2.030 orang di Kantor Imigrasi (kanim), 4.225 orang di community house, dan sebanyak 5.993 merupakan imigran mandiri. Dalam hal ini Indonesia hanya memiliki 13 (tiga belas) rudenim, tetapi hanya 1 (satu) rudenim yang kapasitasnya memadai yaitu di Jayapura. ${ }^{2}$

Pengungsi dan pencari suaka
merupakan salah satu kelompok
masyarakat rentan, seringkali mengalami perlakuan diskriminatif dan pelanggaran hak asasi manusia, sehingga membutuhkan perhatian khusus dan perlindungan Negara

1. Balitbang HAM, Buku Pedoman HAM bagi Petugas Rumah Detensi Imigrasi, Balitbang HAM Kemenkumham, 2011.

2. Galang Aji Putro, 14.425 Imigran Ilegal Penuhi Indonesia, Ini Langkah Pemerintah, DetikNews 9 Maret 2017, diakses melalui https://news.detik.com/berita/d-3442963/14425-imigran-ilegal-penuhi-indonesia-ini-langkah-pemerintah 
untuk menghindari eksploitasi atau dari lingkungan yang berbahaya. ${ }^{3}$ Lebih lanjut Besmellah Rezaee mengemukakan bahwa Pengungsi adalah kelas yang paling rentan di dunia. Mereka tidak memiliki perlindungan dari negara manapun sampai dan kecuali mereka diberi. Situasi putus asa mereka harus mewajibkan orang lain untuk memperlakukan mereka dengan kesadaran penuh kasih bahwa pengungsi adalah manusia dan kerentanan mereka tidak boleh dipolitisasi untuk tujuan yang tidak etis. ${ }^{4}$

Pernyataan tersebut berarti bahwa pengungsi tidak mendapatkan perlindungan dari Negara asal ataupun Negara penerima. Perlindungan yang ada dari Negara penerima masih sangat minim. Begitupun dengan Indonesia, ada beberapa faktor yang mengakibatkan para Pengungsi dan Pencari Suaka tidak mendapatkan perlindungan efektif di Indonesia. Faktor-faktor ini antara lain ${ }^{5}$ kurangnya perlindungan hukum, lamanya masa tunggu untuk proses penempatan ke negara ketiga secara permanen, terbatasnya bantuan kebutuhan dasar seperti hak atas tempat tinggal dan kesehatan) serta keberadaan institusi (baik kapabilitas dan kapasitas) Rumah Detensi Imigrasi (Rudenim) yang harus didukung dalam pengelolaan dan penanganan pengungsi dari luar negeri dalam kerangka penghormatan hak asasi manusia.

Diberlakukannya Peraturan Presiden Nomor 125 Tahun 2016 tentang Penanganan Pengungsi dari Luar Negeri, dapat diasumsikan sebagai komitmen Negara dalam melaksanakan ketentuan Pasal 27 ayat
(2) Undang-Undang Nomor 37 Tahun 1999 tentang Hubungan Luar Negeri, khususnya menangani masalah pengungsi serta komitmen dalam menghormati dan melindungi hak asasi manusia. Berdasarkan Peraturan Presiden No.125 Tahun 2016, bahwa penanganan pengungsi dikoordinasikan oleh Menteri $^{6}$, yang dalam hal ini Kementerian yang membidangi urusan pemerintahan di bidang politik, hukum, dan keamanan. Koordinasi di maksud salah satunya adalah dalam hal Pengawasan Keimigrasian. ${ }^{7}$

Kewenangan pengawasan keimigrasian bagi pengungsi dilakukan oleh petugas Rumah Detensi Imigrasi ${ }^{8}$ dan pengawasan keimigrasian tersebut meliputi; saat ditemukan, di tempat penampungan dan diluar tempat penampungan, diberangkatkan ke negara tujuan, pemulangan sukarela, dan pendeportasian. $^{9}$

Dalam praktek sebelumnya kewenangan pengawasan keimigrasian dilakukan oleh Kantor Imigrasi, sehingga peralihan kewenangan ini akan berdampak pada kapasitas dan kapabilitas institusi Rumah Detensi Imigrasi dalam pengelolaan dan pengawasan pengungsi dari luar negeri. Dengan bertambahnya pelaksanaan tugas dan wewenang Rudenim terhadap pengungsi dan pencari suaka, sebagaimana yang diatur di dalam Peraturan Presiden Nomor 125 Tahun 2016, maka secara eksplisit institusi keimigrasian, dalam hal ini Direktorat Jenderal Imigrasi berkewajiban menetapkan kebijakan yang menunjang tugas dan wewenang Rudenim dalam melaksanakan peraturan

3. University of Pune, "Human Rights Vulnerable and Disadvantaged Groups" (Course Book-II), University of Pune Press, Pune, 2012, h. 11

4. Besmellah Rezaee, "The Human Face of Refugee Policy", Right Now 15 April 2014, diakses melalui http://rightnow. org.au/opinion-3/the-human-face-of-refugee-policy/.

5. Suaka, masalah Perlindungan diakses melalui https://suaka.or.id/public-awareness/id-masalah-perlindungan/ pada 5 Juni 2017

6. Pasal 4 ayat (1) huruf d Peraturan Presiden Nomor 125 Tahun 2016 tentang Penanganan Pengungsi dari Luar Negeri

7. Pasal 4 ayat (2) huruf d Peraturan Presiden Nomor 125 Tahun 2016

8. Pasal 33 ayat (1) Peraturan Presiden Nomor 125 Tahun 2016

9. Pasal 33 ayat (2) Peraturan Presiden Nomor 125 Tahun 2016 
presiden dimaksud mengingat secara kelembagaan belum adanya perubahan struktur organisasi sejak pelimpangan kewenangan rudenim dalam penanganan pengungsi dan pencari suaka. Oleh karena itu, belum adanya perubahan kelembagaan akan mempengaruhi berbagai unsur lainnya seperti ketatalaksanaan, infrastruktur, dan perencanaan dalam pelaksanaan tugas rudenim sebagai akibat banyaknya pengungsi yang harus ditangani Rudenim dengan keterbatasan pegawai, sarana dan prasarana di Rudenim.

Dalam konteks pengawasan keimigrasian, baik di tempat penampungan maupun di luar penampungan, sebagaimana yang telah diatur di dalam Pasal 35 dan Pasal 36 Peraturan Presiden No. 125 Tahun 2016 tentang Penanganan Pengungsi dari Luar Negeri, tentunya dapat diasumsikan sebagai bentuk pengawasan keimigrasian yang bersifat adminstratif dan belum menyentuh pada aspek penghormatan hak pengungsi sebagai manusia, terutama dalam hal menghormati hak-hak ekonomi, sosial dan budaya para pengungsi, yang bersifat teknis. Mengingat permasalahan penanganan pengungsi dan pencari suaka, baik di tempat penampungan dan di luar penampungan sangat beragam, seperti misalnya masalah sosial kemasyarakatan dengan lingkungan sekitar, masalah pemenuhan hak-hak ekonomi dan masalah lainnya, maka menarik untuk diteliti tentang bagaimana kapabilitas dan kapasitas Rumah Detensi dalam penanganan permasalahan dimaksud dalam kerangka pelaksanaan Peraturan Presiden Nomor 125 Tahun 2016

Meskipun Indonesia belum meratifikasi Konvensi 1951 dan Protokol 1967 mengenai Status Pengungsi, namun Pemerintah Indonesia tetap berkomitmen dalam menghormati hak asasi manusia yang berlaku secara universal. Komitmen tersebut ditunjukkan dengan dibentuknya
Peraturan Presiden No. 125 Tahun 2016 tentang Penanganan Pengungsi dari Luar Negeri. Atas dasar keinginan Pemerintah Indonesia untuk terus mengevaluasi kinerja penghormatan hak asasi manusia terhadap pengungsi dan pencari suaka di Indonesia.

\section{Rumusan Masalah}

Adapun rumusan masalah pada penelitian ini adalah Bagaimana penanganan pengungsi dari luar negeri sesuai dengan Peraturan Presiden Nomor 125 Tahun 2016, khususnya dilihat dari asepk Kelembagaan, ketatalaksanaan dan Infrastruktur?

\section{Tujuan}

Tujuan penelitian adalah untuk mendapatkan deskripsi tentang Penanganan Pengungsi dari Luar Negeri sesuai dengan Peraturan Presiden No. 125 Tahun 2016, khususnya dilihat dari aspek Kelembagaan, ketatalaksanaan dan Infrastruktur

\section{Metode Penelitian}

\section{Pendekatan}

Penelitian ini merupakan jenis penelitian deskriptif dengan menggunakan pendekatan kualitatif. Penelitian deskriptif menghadirkan gambaran tentang situasi secara detil. Penelitian ini berupaya mendeskripsikan secara jelas mengenai penanganan pengungsi sebagai akibat adanya peralihan kewenangan pengawasan keimigrasian yang semula dilakukan oleh Kantor Imigrasi kemudian menjadi kewenangan Rumah Detensi Imigrasi. Penelitian deskriptif biasanya berfokus pada pertanyaan "bagaimana (how)" dan "siapa (who)". Pendekatan kualitatif digunakan agar dapat mengeksplorasi: proses, para pihak, serta konteks Pengawasan Keimigrasian oleh Rudenim terkait pelaksanaan Peraturan Presiden No.125 Tahun 2016. Pendekatan dimaksud juga digunakan untuk mengidentifikasi terhadap potensi tantangan dan hambatan atas peralihan kewenangan 
pengawasan keimigrasian kepada Rumah Detensi Imigrasi.

\section{Metode Pengumpulan Data}

Metode pengumpulan data dilakukan melalui wawancara kepada para pejabat Rudenim dan para pengungsi di Makassar provinsi Sulawesi Selatan. Menurut Moh Nazir sebagaimana dikutip oleh H.M. Burhan Bungin, mengemukakan bahwa yang dimaksud wawancara atau interviu adalah sebuah proses memperoleh keterangan untuk tujuan penelitian dengan cara tanya jawab sambil bertatap muka antara pewawancara dengan responden atau orang yang diwawancarai dengan atau tanpa menggunakan pedoman (guide) wawancara. ${ }^{10}$ Dalam hal ini wawancara dilakukan dengan dengan menggunakan pedoman wawancara berdasarkan parameter yang telah disusun sebelumnya.

\section{Teknik Analisa Data}

Pendekatan analisis yang digunakan dalam penelitian ini adalah pendekatan expost facto. Penelitian expost facto adalah penelitian yang dilakukan untuk meneliti peristiwa yang telah terjadi dan kemudian merunut ke belakang melalui data untuk menemukan faktor-faktor yang mendahului atau menentukan sebab-sebab yang mungkin atas peristiwa yang diteliti.

\section{PEMBAHASAN}

\section{Pengungsi, Pencari Suaka dan Hak-Hak yang dimiliki}

Pengungsi dan pencari suaka merupakan permasalahan yang sampai saat ini dihadapi oleh Indonesia karena letak geografis Indonesia yang sangat strategis, sehingga dijadikan transit bagi pengungsi dan pencari suaka untuk mencapai negara yang diharapkan. Sebelum melakukan pembahasan lebih jauh mengenai pengungsi dan pencari suaka, perlu diketahui terlebih dahulu mengenai pengertian dua istilah tersebut

BerkenaandenganhaltersebutAlexander Bett and Gil Loescher mengemukakan pendapatnya tentang pengungsi sebagai berikut: Refugees are people who cross international borders in order to flee human right abuses and conflict. Refugees are prima face evidence of human rights violation and vulnerability.People who are persecuted and deprived of their homes and communities and means of livelihood are frequently forced to flee across the borders of their home countries and seek safety abroad. ${ }^{11}$

Pengertian tersebut berarti bahwa Pengungsi adalah orang-orang yang melintasi perbatasan internasional untuk melarikan diri dari pelanggaran hak asasi manusia dan konflik. Pengungsi adalah bukti prima face pelanggaran hak asasi manusia dan kerentanan. Orang yang dianiaya, rumah dan mata pencahariannya dirampas, sehingga mereka terpaksa melarikan diri melintasi perbatasan dari negara asal mereka dan mencari keselamatan di luar negeri.

Konvensi 1951 tentang Status Pengungsi, mendefinisikan pengungsi sebagai "orang yang dikarenakan oleh ketakutan yang beralasan akan penganiayaan, yang disebabkan oleh alasan ras, agama, kebangsaan, keanggotaan dalam kelompok sosial dan partai politik tertentu, berada diluar Negara kebangsaannya dan tidak menginginkan perlindungan dari Negara tersebut." 12

10. H.M. Burhan Bungin, Metodologi Penelitian Kuantitatif (Komunikasi, Ekonomi, dan Kebijakan Publik Serta IImu-IImu Sosial Lainnya), Kencana, Jakarta, 2017, hlm 136

11. Alexander Betts and Gil Loescher (Ed.), Refugee in International Relation. (New York: Oxford University Press, 2011) hlm. 1

12. UNHCR Indonesia, diakses melalui http://www.unhcr.org/id/pengungsi pada tanggal 10 Juni 2017 
Dari kedua pengertian mengenai pengungsi dapat dikemukakan bahwa seseorang dapat dikatakan sebagai pengungsi bila ia pergi dari negaranya sebagai akibat adanya pelanggaran hak-hak asasi dinegaranya, baik berupa penyiksaan fisik dan batin, sehingga perlu menyelamatkan diri ke negara lain

Sedangkan pencari suaka dapat dikemukakan pengertiannya menurut The United Nations High Commissioner for Refugees (UNHCR) yang menyatakan bahwa seorang pencari suaka adalah seseorang yang menyebut dirinya sebagai pengungsi, namun permintaan mereka akan perlindungan belum selesai dipertimbangkan. Seorang pencari suaka yang meminta perlindungan akan dievaluasi melalui prosedur penentuan status pengungsi (RSD), yang dimulai sejak tahap pendaftaran atau registrasi pencari suaka. Selanjutnya setelah registrasi, UNHCR dibantu dengan penerjemah yang kompeten melakukan interview terhadap pencari suaka tersebut. Proses interview tersebut akan melahirkan alasan-alasan yang melatarbelakangi keputusan apakah status pengungsi dapat diberikan atau ditolak. Pencari suaka selanjutnya akan diberikan satu buah kesempatan untuk meminta banding atas permintaannya akan perlindungan internasional yang sebelumnya

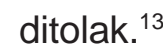

Jadi yang dimaksud pencari suaka disini adalah orang-orang yang meminta perlindungan dan mengajukan permohonan kepada UNHCR untuk dapat menjadi pengungsi. Sehingga dapat dikatakan bahwa pencari suaka adalah bukanlah pengungsi sehingga tidak dapat dilindungi dan dibawah tanggung jawab UNHCR sebelum sampai pada negara tujuan walaupun tujuannya sama yaitu meminta perlindungan, sementara pengungsi sudah pasti adalah merupakan pencari suaka yang setelah melalui proses berhak mendapatkan status pengungsi dan selanjutnya menjadi tanggung jawab dari UNHCR sesuai dengan konvensi 1951 tentang pengungsi. ${ }^{14}$

Dalam Pasal 1 C Konvensi 1951 tersebut memberikan persyaratan kepada seseorang untuk dihentikan statusnya sebagai pengungsi apabila:

(1) la secara sukarela memanfaatkan perlindungan negara kewarganegaraannya ; atau

(2) Setelah kehilangan kewarganegaraannya, ia secara sukarela telah memperolehnya kembali; atau

(3) la telah memperoleh kewarganegaraan baru, dan menikmat perlindungan negara kewarganegaraan barunya; atau

(4) la secara sukarela telah menetap kembali di negara yang ditinggalkannya atau di luar negara itu di mana ia tetap tinggal karena kecemasan akan persekusi; atau

(5) la tidak dapat lagi, karena keadaankeadaan yang berhubungan dengan pengakuanatasdirinyasebagaipengungsi sudah tidak ada lagi, tetap menolak untuk memanfaatkan perlindungan negara kewarganegaraannya

(6) Sebagai seorang yang tidak mempunyai kewarganegaraan, karena keadaankeadaan yang berhubungan dengan pengakuan atas dirinya sebagai pengungsi sudah tidak ada lagi, ia dapat kembali ke negara di mana ia sebelumnya bertempat tinggal.

Untuk menjamin status hukum pengungsi di negara pemberi suaka, konvensi mengandung ketetapan-ketetapan komprehensif mengenai hak-hak pengungsi. Kecualibilahak-hakyanglebihmenguntungkan

\footnotetext{
13. In Karita Sakharina dan Kadarudin, Pengantar Hukum Pengungsi Internasional (Perbedaan istilah Pencari Suaka, Pengungsi Internasional dan Pengungsi dalam Negeri), Deepublish, Yogyakarta, 2017, hlm 24

14. Ibid. hlm 25
} 
dinyatakan secara jelas dalam konvensi, para pengungsi diberi standar minimum hak yang sama sebagaimana diberikan kepada orang asing pada umumnya. Seorang pengungsi juga diberi hak-hak khusus yang normalnya tidak dinikmati oleh orang asing karena adanya kenyataan bahwa dia tidak mendapat perlindungan dari negara dimana dia adalah warganegaranya. Hak-hak pengungsi adalah sebagal berikut:

1. Hak untuk tidak dipulangkan ke suatu negara dimana mereka mempunyai alasan untuk takut terhadap suatu persekusi.

2. Hak untuk tidak diusir, kecuali dalam keadaan-keadaan tertentu, seperti keamanan nasional dan ketertiban umum.

3. Pengecualian dari hukuman karena masuk secara tidak sah ke wilayah negara yang menjadi pihak pada Konvensi karena keadaan dimana para pengungsi terpaksa meninggalkan tanah air mereka, maka boleh jadi tidak mungkin bagi mereka untuk masuk ke negara yang berpontensi memberi suaka kepada mereka dengan cara yang biasa, misalnya dengan paspor atau visa masuk yang sah. Biasanya, masuk atau keberadaan secara tidak sah seperti itu, bagaimanapun juga, tidak boleh dijatuhkan terhadap pengungsi.

4. Hak bergerak dengan bebas, negaranegara peserta secara hukum wajib memberikan kepada pengungsi di wilayah mereka hak untuk memilih tempat tinggal dan bergerak secara bebas di dalam wilayah mereka, sesuai dengan peraturan yang berlaku bagi orang asing pada umumnya pada kondisi yang sama.

5. Kebebasan beragama dan akses yang bebas ke pengadilan.
6. Identitas dan dokumen perjalanan.

7. Hak untuk mendapatkan pekerjaan dan perumahan.

8. Akses untuk mendapatkan pendidikan formal.

9. Bantuan pemerintah dan peraturan perburuhan serta jarninan sosial ${ }^{15}$

Dengan adanya hak-hak yang telah dikemukakan, maka dapat diketahui bahwa para pengungsi tidak dengan sendirinya kehilangan haknya karena pencabutan kewarganegaraannya dari negara asal mereka. Hak-hak ini termasuk hak untuk masuk ke dalam suatu negara dimana mereka berharap dapat hidup secara lebih baik. Oleh karena itu negara memiliki kewajiban untuk menerima pengungsi dari negara lain, berusaha meningkatkan kesejahteraan mereka, memampukan mereka menjadi anggota masyarakat yang telah mereka pilih. Dalam situasi dimana jumlah pengungsi bertambah secara luar biasa ditahun-tahun terakhir ini-walaupun pembatasan bagi masuknya mereka juga berlanjut-maka pentinglah untuk mengusahakan hak-hak mereka. ${ }^{16}$

\section{Perlindungan Pengungsi dan Pencari Suaka di Indonesia}

Indonesia merupakan salah satu negara yang mengakui, menghormati dan menjunjung tinggi nilai-nilai Hak Asasi Manusia. Hal ini dikarenakan Hak Asasi Manusia adalah seperangkat hak yang melekat pada hakikat dan keberadaan manusia sebagai makhluk Tuhan Yang Maha Esa dan merupakan anugerah-Nya yang wajib dihormati, dijunjung tinggi dan dilindungi oleh negara, hukum, Pemerintah, dan setiap orang demi kehormatan serta perlindungan harkat dan martabat manusia sebagaimana

15. Fadli Afriandi dan Yusnarida Eka Nizmi, Kepentingan Indonesia Belum Meratifikasi Konvensi 1951 Dan Protokol 1967 Mengenai Pengungsi Internasional Dan Pencari Suaka, Transnasional: Jurnal Ilmu Hubungan Internasional Universitas Riau Vol 5 No. 2 Tahun 2014

16. Paul Vallely (ed.), Cita Masyarakat Abad 21 : Visi Gereja tentang Masa Depan, Kanisius, Yogyakarta, 2007 , hal 69 
yang diamanatkan dalam Undang-Undang Republik Indonesia Nomor 39 Tahun 1999 tentang Hak Asasi manusia.

Berdasarkan pengertian mengenai HAM tersebut, maka dapat dikemukakan bahwa HAM merupakan sekumpulan hak yang bersifat normatif atau merupakan legal rights. Sifat normatif ditandai dengan adanya landasan hukum secara internasional yang mengatur HAM. Norma-norma HAM yang terdapat di dalam instrumen hukum HAM internasional selanjutnya menciptakan kewajiban bagi negara untuk melindungi dan menjamin HAM bagi setiap individu. ${ }^{17}$

Oleh karena itu walaupun Indonesia bukanlah negara yang ikut dalam penandatangan Konvensi 1951 dan Protokol 1967 tentang status pengungsi, namun Indonesia mengakui dan menghormati akan hak atas rasa aman dari pengungsi dan pencari suaka sesuai dengan yang tercantum dalam pasal Pasal 28 ayat (1) Undang-Undang RI Nomor 39 Tahun 1999 Tentang Hak Asasi Manusia tersebut, yang menyatakan bahwa setiap orang berhak mencari suaka untuk memperoleh perlindungan politik dari negara lain.

Hal ini dapat terlihat pada Provinsi Sulawesi Selatan yang merupakan salah satu wilayah tujuan dari pengungsi dikarenakan lokasinya yang strategis, sehingga menyebabkan provinsi tersebut menjadi poros maritim pengungsi dari berbagai negara. Adapun jumlah pengungsi ataupun pencari suaka di provinsi tersebut dapat diketahui dari data yang ada pengungsi yang berada di tempat-tempat penampungan sebagai berikut :
Tabel 1. Jumlah Pengungsi Pada Penampungan

\begin{tabular}{l|l|l}
\hline NO & Negara & Jumlah \\
\hline 1 & Afghanistan & 1.154 \\
2 & Myanmar & 216 \\
3 & Somalia & 164 \\
4 & Sudan & 65 \\
5 & Iran & 66 \\
6 & Pakistan & 42 \\
7 & Iraq & 43 \\
8 & Sri Langka: & 38 \\
9 & Ethiopia & 28 \\
10 & Palestina & 12 \\
11 & Yaman & 2 \\
12 & Eurotopia & 1 \\
13 & Egypt & 1 \\
\hline
\end{tabular}

Sumber : Rudenim Makassar, 2017

Berdasarkan data-data pada tabel 1 dapat terlihat bahwa sebagian besar pengungsi yang terdapat di Makassar provinsi Sulawesi Selatan berasal dari negara Afghanistan yaitu sebanyak 1.154 orang. Sedangkan posisi kedua terbanyak pengungsi berasal dari negara Myanmar yaitu sebanyak 216 orang.

Akan tetapi Indonesia tidak memiliki kerangka legislatif bagi perlindungan pencari suaka dan pengungsi sebagai akibat belum meratifikasi Konvensi 1951 dan Protokol 1967 tentang status pengungsi tersebut. Dalam ketiadaan peraturan perundangundangan dan prosedur-prosedur nasional bagi pengungsi tersebut, UNHCR mengisi peran sebagai penyedia utama perlindungan dan bantuan bagi para pengungsi dan pencari suaka. ${ }^{18}$

UNHCR beroperasi di Indonesia dengan persetujuan dari Pemerintah Republik Indonesia. Direktur Jenderal Imigrasi mengeluarkan Instruksi pada tahun 2010 (No:IMI-1489.UM.08.05) yang menyatakan

17. Andrey Sujatmoko, Tanggung Jawab Negara atas Pelanggaran Berat HAM Indonesia, Timor Leste dan lainnya, Grasindo, Jakarta, 2005, hal 63

18. Antje Missbach, Troubled Transit : Politik Indonesia Bagi Para Pencari Suaka, penerjemah: Mayolisia Ekayanti, Edisi pertrama, Jakarta, Yayasan Pustaka Obor Indonesia, 2016, hlm. 151 
bahwa orang-orang yang mencari suaka atau status pengungsi harus dirujuk kepada UNHCR untuk mengikuti proses penentuan status sebagai Pengungsi dan bahwa "status dan kehadiran orang asing yang memegang Attestation Letters atau kartu identitas yang dikeluarkan oleh UNHCR sebagai Pencari Suaka, Pengungsi atau orang yang dilayani oleh UNHCR, harus dihormati". Orangorang yang tak memiliki dokumen-dokumen tersebut akan terancam untuk dimasukkan ke dalam Rumah Detensi Imigrasi, terkena denda, dan/atau dideportasi. Walaupun UNHCR beroperasi di Indonesia dengan izin dari Pemerintah Indonesia, kapasitasnya sangat terbatas oleh karena meningkatnya jumlah Pencari Suaka yang mencari bantuan di Indonesia. UNHCR memiliki 60 staff di Indonesia. ${ }^{19}$

Para Pencari Suaka yang telah terdaftar dapat mengajukan Pengakuan Status sebagai Pengungsi yang dinilai oleh UNHCR melalui proses yang disebut prosedur Penentuan Status sebagai Pengungsi (Refugee Status Determination/RSD). Para Pencari Suaka diwawancarai oleh petugas RSD yang dibantu oleh seorang penerjemah berkaitan dengan pengajuan mereka untuk mendapatkan perlindungan. Ketika pengajuan untuk mendapatkan perlindungan ditolak, prosedur RSD masih memberikan satu kesempatan lagi untuk mengajukan banding atas keputusan negatif itu. ${ }^{20}$

Pada umumnya, bantuan dan nasihat hukum tidak disediakan, sehingga banyak keputusan negatif itu merupakan akibat dari Pencari Suaka yang tidak memahami proses yang harus mereka patuhi, akibat dari kendala bahasa, ketakutan untuk berbicara kepada pihak yang berwenang, dan karena mereka tidak mengetahui hak dan tanggung jawab mereka sebagai orang yang mengajukan status sebagai Pengungsi. Dalam praktiknya, hak untuk mendapatkan Penasihat Hukum bagi para Pencari Suaka dan Pengungsi juga belum sepenuhnya diakui oleh UNHCR dan pemerintah. Hal ini membahayakan integritas proses RSD karena Pencari Suaka tidak sepenuhnya menyadari hak-hak dan tanggung jawab mereka, maupun proses yang melibatkan mereka. ${ }^{21}$

Salah satu mitra utama non-pemerintah UNHCR di Indonesia adalah IOM, yang khusus menangani persoalan penahanan, program perumahan masyarakat dan pengaturan perjalanan bagi penempatan dan repatriasi sukarela para pengungsi serta pemulangan pencari suaka secara sukarela yang difasilitasi (assisted voluntary return of asylum seeker) dan hal-hal lain yang menjadi perhatian. Hubungan antara kedua organisasi internasional tersebut cukup rumit, tidak hanya di Indonesia, namun juga di negara lainnya. Hubungan antara IOM dan UNHCR memiliki sejarah panjang yang ditandai dengan kerjasama yang erat dan persaingan karena adanya tumpang tindih dalam pelaksanaan tugas. Meskipun IOM tidak memiliki mandat pengungsi, namun IOM telah banyak terlibat dalam kegiatan penanganan yang berdampak pada pengungsi dan pencari suaka (yang ditolak), seperti di Indonesia. Akibatnya, persaingan pendanaan yang berkaitan dengan pengungsi kian meningkat diantara kedua pemain tersebut. Sementara UNHCR di Indonesia terus menerus mengalami kekurangan dana dan staf, IOM berada dalam posisi keuangan yang sangat menguntungkan. ${ }^{22}$

19. Diakses melalui https://suaka.or.id/public-awareness/id-masalah-perlindungan/

20. Ibid.,

21. Ibid.,

22. Antje Missbach,op.cit., hlm155 
Salah satu tugas paling penting yang dilakukan UNHCR adalah menentukan status pencari suaka yang mencari perlindungan, dimana Indonesia sepenuhnya mengandalkan UNHCR. Setelah pencari suaka menghubungi UNHCR di Jakarta atau anggota stafnya ketika mereka mengunjungi rudenim dimana pun di Indonesia, mereka dapat mengajukan permohonan perlindungan internasional. Langkah pertama proses penentuan status pengungsi UNHCR adalah pemeriksaan identitas pemohon. Setelah pemeriksaan, orang-orang dapat secara resmi mendaftar dan menerima dokumentasi sementara dalam bahasa Inggris atau bahasa Indonesia, yang menyatakan status mereka sebagai pencari suaka. Sertifikat pencari suaka ini berisi foto pencari suaka, informasi dasar, sebagai nama dan tanggal lahir, serta yang paling terbaru, secara tegas menyebutkan bahwa pemegang sertifikat adalah "orang yang menjadi perhatian Kantor United Nation High Commissioner for Refugees dan harus secara khusus, dilindungi dari pemulangan paksa ke negara yang mengancam nyawa atau kebabasannya, sambil menanti keputusan akhir status pengungsinya. Dokumentasi sementara ini harus diperbaharui setiap dua hingga tiga bulan untuk memastikan bahwa pemohon masih ada di Indonesia dan belum pindah. ${ }^{23}$

Kedudukan Peraturan Presiden tentang Penanganan Pengungsi dari Luar Negeri (PPLN) terhadap Undang Undang Keimigrasian

Berdasarkan Undang-Undang Republik Indonesia Nomor 6 Tahun 2011 Tentang Keimigrasian (UU Keimigrasian), Rumah Detensi Imigrasi (Rudenim) merupakan salah satu unit pelaksana teknis di lingkungan Kementerian Hukum dan HAM RI yang menjalankan fungsi keimigrasian sebagai tempat penampungan sementara bagi Orang
Asing yang dikenai Tindakan Administratif Keimigrasian (TAK), sebagaimana diatur dalam Pasal 83 ayat (1) undang-undang dimaksud. Didalam perjalanannya, Rudenim tidak saja difungsikan sebagai tempat menampung Orang Asing yang dikenai TAK namun juga sebagai tempat penampungan pengungsi dan pencari suaka dari luar negeri. Hal tadi disebabkan oleh karena keterbatasan tempat penampungan pengungsi dan pencari suaka yang ada dalam satu wilayah tertentu. Meskipun ini merupakan fenomena "pergeseran" tugas fungsi Rudenim, namun hal ini sudah menjadi kebijakan yang harus dilaksanakan, sehingga keberadaan Rudenim sangat dibutuhkan di Indonesia mengingat Indonesia memiliki posisi strategis untuk dikunjungi oleh orang asing dengan berbagai tujuan, baik tujuan wisata, mencari pekerjaaan ataupun tujuan lainnya (termasuk mengungsi dan mencari suaka).

Sejak rezim pemerintahan yang baru (masa pemerintahan Presiden Joko Widodo), pemerintah mengeluarkan kebijakan penanganan pengungsi melalui Peraturan Presiden Nomor 125 Tahun 2016 tentang Penanganan Pengungsi dari Luar Negeri atas dasar melaksanakan ketentuan Pasal 27 ayat (2) Undang-Undang Nomor 37 Tahun 1999 tentang Hubungan Luar Negeri. Pada pasal 33 sampai dengan Pasal 39 di dalam Peraturan Presiden No. 125 Tahun 2016, diatur ketentuan mengenai kewenangan pengawasan keimigrasian oleh Rudenim.

Berdasarkan deskripsi dua ketentuan yang mengatur tentang kewenangan Rudenim tersebut, maka perlu memposisikan ketentuan pasal-pasal yang disebutkan di dalam Peraturan Presiden Nomor 125 Tahun 2016 tentang Penanganan Pengungsi dari Luar Negeri yang mengatur kewenangan pengawasan keimigrasian oleh Rudenim terhadap UU Keimigrasian

23. Ibid., hlm 157 
yang juga mengatur kewenangan Rudenim. Jika melihat pada sisi "subjek" yang diatur dan menjadi fokus kewenangan Rudenim diantara UU Keimigrasian dan Peraturan Presiden Nomor 125 Tahun 2016 tentang Penanganan Pengungsi dari Luar Negeri maka keduanya memiliki persamaan. Keduanya sama-sama menggunakan istilah "Orang "Asing", baik "orang asing" itu sendiri maupun "pengungsi sebagai orang asing" yang memiliki pengertian sebagai "orang yang bukan warga Negara Indonesia". Perbedaannya adalah terletak pada cara penanganannya. Di dalam ketentuan Undangundang Keimigrasian kewenangan Rudenim adalah melaksanakan fungsi keimigrasian sebagai tempat penampungan orang asing yang mendapatkan TAK, yang meliputi kewenangan: pendetensian, pengisolasian, pendeportasian, pemulangan, pemindahan, dan fasilitasi penempatan ke negara ketiga terhadap Orang Asing di Wilayah Indonesia yang melakukan pelanggaran ketentuan peraturanperundang-undangan. ${ }^{24}$ Sedangkan didalam ketentuan Peraturan Presiden Nomor 125 Tahun 2016 tentang Penanganan Pengungsi dari Luar Negeri kewenangan Rudenim adalah melakukan pengawasan keimigrasian terhadap pengungsi dan pencari suaka yang meliputi: pada saat ditemukan, di tempat penampungan dan diluar tempat penampungan, diberangkatkan ke negara tujuan, pemulangan sukarela, dan pendeportasian. Dengan demikian, berdasarkan hal tersebut, maka dapat dikatakan bahwa Peraturan Presiden Nomor 125 Tahun 2016 tentang Penanganan Pengungsi dari Luar Negeri merupakan peraturan khusus (lex specialis) dari Undangundang Keimigrasian yang mengatur khusus penanganan pengungsi dari luar negeri, yang dalam hal ini kedudukannya sama-sama sebagai "orang asing". Dalam kondisi tersebut Undang-undang Keimigrasian tidak mengatur penanganan pengungsi dari luar negeri.

Pelaksanaan Peraturan Presiden Nomor 125 Tahun 2016 tentang Penanganan Pengungsi dari Luar Negeri oleh Rudenim Makassar

$\begin{array}{lrr}\text { Pemberlakukan Peraturan } & \text { Presiden } \\ \text { Nomor } 125 \quad \text { Tahun } 2016 & \text { tentang } \\ \text { Penanganan Pengungsi dari Luar Negeri } & \text { Nerim } \\ \text { sangat mempengaruhi } & \text { Rudenim secara }\end{array}$ kelembagaan dan ketatalaksanaan, infrastruktur dan perencanaan selanjutnya. Di dalam pembahasan analisis pelaksanaan Peraturan Presiden Nomor 125 Tahun 2016 tentang Penanganan Pengungsi dari Luar Negeri oleh Rudenim, akan disampaikan dalam dua perspektif, yaitu: perspektif kondisi Rudenim dalam melaksanakan tugas sebelumnya serta kondisi Rudenim pada saat ini setelah diberlakukannya Peraturan Presiden Nomor 125 Tahun 2016 tentang Penanganan Pengungsi dari Luar Negeri.

Pada kondisi sebelum adanya Peraturan Presiden Nomor 125 Tahun 2016 tentang Penanganan Pengungsi dari Luar Negeri, pelaksanaan Rudenim selain sebagai tempat penampungan orang asing yang dikenai tindakan administratif keimigrasian (TAK), juga sekaligus menjadi tempat penampungan bagi orang asing yang berstatus sebagai pengungsi dan pencari suaka, meskipun mereka sebagian berada di tempat penampungan lainnya yang dikelola oleh IOM. Kebijakan untuk menjadikan Rudenim sekaligus sebagai penampungan para pengungsi dan pencari suaka secara tidak langsung menjadi beban tambahan tugas bagi Rudenim, yang pada akhirnya menjadi berdampak pada beban Rudenim secara kelembagaan dan ketatalaksanaan.

24. Peraturan Direktur Jenderal Imigrasi Nomor IMI.1917-OT.02.01 Tahun 2013 Tentang Standar Operasional Prosedur (SOP) Rumah Detensi Imigrasi 
Dilihat dari aspek kelembagaan dan ketatalaksanaan, dapat dikemukakan bahwa belum terdapat perubahan struktur kelembagaan Rudenim setelah adanya Peraturan Presiden Nomor 125 Tahun 2016 tentang Penanganan Pengungsi dari Luar Negeri. Akan tetapi terdapat pelimpahan kewenangan pengawasan dari Kantor Imigrasi Kelas I Makasar kepada Rumah Detensi Imigrasi Makasar yang terletak di Kabupaten Gowa.

Hal ini menjadi salah satu permasalahan karena secara kelembagaan, standar operasional prosedur (SOP) yang digunakan adalah SOP berdasarkan pada Peraturan Direktur Jenderal Imigrasi Nomor IMI.1917OT.02.01 Tahun 2013 Tentang Standar Operasional Prosedur (SOP) Rumah Detensi Imigrasi, yang mencakup: pendetensian, pengisolasian, pendeportasian, pemulangan, pemindahan, dan fasilitasi penempatan ke negara ketiga terhadap OrangAsing diWilayah Indonesia yang melakukan pelanggaran ketentuan peraturan perundang-undangan (Deteni). Dalam hal ini, jelas bahwa SOP dimaksud ditujukan sebatas pada Deteni dan tidak termasuk kepada pengungsi dan pencari suaka. Namun di sisi lain, secara empirik tugas-tugas Rudenim juga dibebani pada pengawasan pengungsi dan pencari suaka yang ditampung pada Rudenim dan tempattempat penampungan yang jumlahnya mencapai 30 tempat penampungan, yaitu:

Tabel 2. Jumlah Tempat Penampungan Pengungsi

\begin{tabular}{|l|l|l|}
\hline NO & \multicolumn{1}{|c|}{ Akomodasi } & \multicolumn{1}{|c|}{$\begin{array}{c}\text { Jumlah } \\
\text { Pengungsi }\end{array}$} \\
\hline 1 & IDC Makassar & 135 \\
\hline 2 & Kanim Makassar & - \\
\hline 3 & Bugis Guesthouse 1 & 69 \\
\hline 4 & Kirani Guesthouse 1 & 56 \\
\hline 5 & Kirani Guesthouse 2 & 75 \\
\hline 6 & Pondok Elite-A & 43 \\
\hline 7 & Ida Guesthouse 2 & 69 \\
\hline
\end{tabular}

\begin{tabular}{|l|l|l|}
\hline 8 & Pondok Pelita & 14 \\
\hline 9 & Wisma Mahkota & 81 \\
\hline 10 & Wisma Marindi & 23 \\
\hline 11 & Wisma Permata & 67 \\
\hline 12 & Dinsos UMC Shelter Maysara & 35 \\
\hline 13 & BPPA Female Shelter D'Win & 32 \\
\hline 14 & Pondok Maryam & 23 \\
\hline 15 & Wisma Bajipura & 82 \\
\hline 16 & Wisma Budi & 46 \\
\hline 17 & Wisma D'Khanza & 74 \\
\hline 18 & Wisma Favorite & 48 \\
\hline 19 & Wisma KPI & 158 \\
\hline 20 & Wisma Maysara & 65 \\
\hline 21 & Wisma MSM & 54 \\
\hline 22 & Wisma Mustika 1 & 44 \\
\hline 23 & Wisma Mustika 2 & 53 \\
\hline 24 & Wisma Mustika 3 & 71 \\
\hline 25 & Wisma Re-Re & 183 \\
\hline 26 & 155 Guesthouse-A & 38 \\
\hline 27 & 155 Guesthouse-B & 61 \\
\hline 28 & 155 Guesthouse-C & 35 \\
\hline 29 & Ida Guesthouse1 & 39 \\
\hline 30 & Pondol Elite-B & 59 \\
\hline & Total & 1832 \\
\hline & & \\
\hline
\end{tabular}

Sumber: Rudenim Makassar, 2017

Pelaksanaan tugas yang dilakukan tidak sebanding dengan jumlah sumber manusia yang ada yaitu hanya sebanyak 27 orang saja ${ }^{25}$, dengan komposisi sebagai berikut :

Tabel 3. Jumlah Sumber Daya Manusia Rudenim Makassar

\begin{tabular}{|c|c|c|c|c|}
\hline \multirow[b]{2}{*}{ NO } & \multirow[b]{2}{*}{ Bagian/ Seksi } & \multicolumn{2}{|c|}{ Jenis Kelamin } & \multirow[b]{2}{*}{ JMLH } \\
\hline & & $\begin{array}{l}\text { Laki- } \\
\text { laki }\end{array}$ & $\begin{array}{l}\text { Perem- } \\
\text { puan }\end{array}$ & \\
\hline 1 & Kepala Rudenim & 1 & - & 1 \\
\hline 2 & $\begin{array}{l}\text { Tata Usaha } \\
\text { (yang mencakup } \\
\text { kepegawaian, } \\
\text { Keuangan dan } \\
\text { umum) }\end{array}$ & 8 & 2 & 10 \\
\hline 3 & $\begin{array}{l}\text { Registrasi, } \\
\text { Administrasi } \\
\text { dan Pelaporan } \\
\text { (yang mencakup } \\
\text { Registrasi dan } \\
\text { Komunikasi } \\
\text { Keimigrasian) }\end{array}$ & 4 & 1 & 5 \\
\hline 4 & $\begin{array}{l}\text { Perawatan } \\
\text { Kesehatan }\end{array}$ & 3 & 1 & 4 \\
\hline \multirow[t]{2}{*}{5} & $\begin{array}{l}\text { Keamanan dan } \\
\text { Ketertiban }\end{array}$ & 6 & 1 & 7 \\
\hline & Jumlah & 22 & 5 & 27 \\
\hline
\end{tabular}

Sumber : Rudenim Makassar, 2017

25. Wawancara dengan Kepala Rudenim Makassar tanggal 6 September 2017 
Tabel 3 menunjukkan adanya keterbatasan jumlah petugas di Rudenim Makassar dalam menjalankan tugas pengawasan terhadap para pengungsi, sehingga untuk mengatasi hal tersebut dilakukan penambahan 11 (sebelas) tenaga honorer dalam membantu penjagaan keamanan di Rudenim Makassar pada malam hari.

Berkenaan dengan pelaksanaan tugas yang dilakukan tersebut, pihak Rudenim Makassar telah berupaya melaksanakan ketentuan yang terdapat dalam Peraturan Presden No 125 Tahun 2016 walaupun masih mengacu pada pedoman dan prosedur yang lama mengingat SOP Pengawasan masih dalam tahap penyelesaian di Ditjen Imigrasi. Hal tersebut tidak mempengaruhi tugas pengawasan yang ada saat ini karena sumber daya manusia yang terdapat pada Rudenim Makassar sangat menguasai berbagai hal yang terkait dengan pengawasan para pengungsi tersebut. Pengawasan yang telah dilakukan pun sangat beragam, baik pengawasan pemulangan secara suka rela, pengawasan pengiriman ke negara tujuan, pengawasan perpindahan antar provinsi ataupun pengawasan di tempat-tempat penampungan. Dalam hal ini pengawasan saat ditemukan sudah jarang terjadi, begitupun dengan pengawasan pengungsi diluar penampungan yang menurut pihak Rudenim hanya terdapat di rumah sakit apabila ada pengungsi yang memerlukan perawatan kesehatan. Selain itu juga ternyata adanya Pelimpahan Kewenangan Pengawasan tidak mempengaruhi anggaran yang ada menjadi lebih baik, bahkan terjadi pemotongan anggaran yang menyebabkan adanya adanya rencana kegiatan yang belum dapat teralisasi. ${ }^{26}$
Dilihat dari aspek infrastruktur yang ada dapat diketahui bahwa prangkat mobilisasi yang digunakan saat ini di Rudenim Makassar masih sangat terbatas yaitu hanya tersedia 1 (satu) mobil dinas yang digunakan untuk melakukan pengawasan. Selain mobil dinas, petugas menggunakan kendaraan pribadi berupa motor bila terdapat panggilan darurat dari berbagai tempat penampungan. Hal ini sangat memprihatinkan mengingat letak Rudenim berada diluar Makassar yaitu di Kabupaten Gowa sehingga membutuhkan waktu yang cukup lama untuk mencapai tempat penampungan yang berada di wilayah Makassar.

Dalam melakukan pengawasan, pihak Rudenim Makassar berupaya melakukan koordinasi dengan berbagai pihak seperti Kepolisian, IOM UNHCR dan sebagainya melalui berbagai media, yang salah satunya adalah melalui perangkat selular baik telepon, sms ataupun grup WhatsApp. Penggunaan perangkat komputer hanya dipergunakan untuk keperluan persuratan saja, sehingga tenaga operator yang ada pun masih memiliki pengetahuan dan keahlian yang standar dalam komputerisasi.

Selain itu, penggunaan perangkat keamanan dalam melakukan pengawasan hanya diperuntukkan bagi penjaga keamanan di Rudenim Makassar saja, baik yang berupa borgol, pentungan, alat kejut listrik dan sebagainya yang penggunaannya harus berdasarkan SOP yang ada di Rudenim.

Pihak Rudenim Makassar menyadari bahwa sistem pengawasan yang ada saat ini masih belum maksimal, terutama berkaitan dengan pembatasan jam keluar para pengungsi yang hanya diperbolehkan dari pukul 15.30 sampai pukul 17.00 WIT sebagai akibat sarana dan prasarana yang belum

26. Wawancara dengan Kepala Rudenim Makassar tanggal 6 September 2017 
tersedia di Rudenim Makassar bagi para pengungsi maupun Imigratoir. Belum adanya sarana dan prasarana tersebut menyebabkan pelaksanaan kegiatan yang berupa olahraga ataupun shalat jumat harus membuka pintu gerbang yang ada karena keterbatasan tempat, sehingga dapat menimbulkan kerawanan atau resiko melarikan diri bagi para deteni atau pengungsi. Oleh karena itu perencanaan pengembangan Rudenim pun sangat diperlukan terutama terkait penyediaan lapangan olah raga, tempat ibadah berupa mesjid atau musholla serta pagar pembatas untuk mensterilkan area tertentu yang belum ada sampai saat ini.

Kemudian, dalam hal pelaksanaan Peraturan Presiden Nomor 125 Tahun 2016 tentang Penanganan Pengungsi dari Luar Negeri oleh Rudenim Makassar, berdasarkan temuan data lapangan (empirical based), pada aspek kebijakan dasar kebijakan yang digunakan oleh rudenim adalah Surat Edaran Direktorat Jenderal Imigrasi No. IMIGR.03.03-1194 Tahun 2017 tentang Pengawasan Keimigrasian Terhadap Pengungsi. Melalui surat edaran ini, pihak Rudenim mulai melaksanakan tugas sebagaimana yang diatur di dalam Peraturan Presiden Nomor 125 Tahun 2016 tentang Penanganan Pengungsi dari Luar Negeri. Meskipun demikian, tidak serta merta segala kesiapan dalam melaksanakan tugas dimaksud telah terpenuhi baik secara kelembagaan dan ketatalaksanaan serta infrastruktur, seperti standar operasional prosedur (SOP), ketersediaan SDM dan infrastruktur. Sebagai contoh, dalam hal infrastruktur, perangkat mobilisasi yang digunakan dalam rangka pelaksanaan tugas pemantauan dan pengawasan tidak efektif oleh karena tidak tersedianya kendaraan khusus guna pelaksanaan tugas dimaksud. Faktor jarak antara kantor Rudenim dengan tempat penampungan di luar Rudenim menjadi faktor penting untuk menjadi perhatian berkaitan dengan penyediaan perangkat mobilisasi petugas dalam melaksanakan tugas pemantauan dan pengawasan keimigrasian. Disamping itu, perangkat keamanan petugas juga belum tersedia secara maksimal bagi petugas serta terbatasnya perangkat teknologi informasi dan komunikasi yang digunakan guna melaksanakan tugas koordinasi dalam penanganan pengungsi dari luar negeri, baik dengan pihak kepolisian, IOM, UNHCR dan sebagainya. Selama ini koordinasi dilakukan melalui perangkat selular baik telepon, sms ataupun grup aplikasi seluler. Penggunaan perangkat komputer hanya dipergunakan untuk keperluan persuratan saja, sehingga tenaga operator yang ada pun masih memiliki pengetahuan dan keahlian yang standar dalam komputerisasi.

Dalam aspek perencanaan, yang termasuk didalam parameter penelitian ini, data empiris menunjukkan bahwa, struktur kelembagaan Rudenim belum disesuaikan dengan tugas fungsi Rudenim berdasarkan Peraturan Presiden Nomor 125 Tahun 2016 tentang Penanganan Pengungsi dari Luar Negeri, yang salah satunya dapat melalui perencanaan perubahan struktur kelembagaan.

Dalam pandangan Swansburg ${ }^{27}$, perencanaan adalah suatu proses berkelanjutan yang diawali dengan merumuskan tujuan dan rencana tindakan yang akan dilaksanakan, menentukan personal, merancang proses dan hasilnya, memberikan umpan balik pada personal, dan memodifikasi rencana yang

27. Swansburg, R.C.\& Swansburg, R.J.. Introductory management \& leadership. (second edition). Jones \& Bartlett Publishers, Boston, 1999 
diperlukan. Penyesuaian ditujukan agar dapat melaksanakan fungsi pengawasan keimigrasian, yang sebelumnya berada pada tugas Kantor Imigrasi setempat. Disamping itu, perubahan struktur kelembagaan akan menentukan pula bagaimana standar operasional prosedur (SOP) dapat disusun terutama dalam hal "siapa dan bagaimana melaksanakan tugas fungsi pengawasan keimigrasian" terhadap pengungsi dan pencari suaka baik meliputi: pada saat ditemukan, di tempat penampungan dan diluar tempat penampungan, pada saat diberangkatkan ke negara tujuan, pemulangan sukarela, dan pendeportasian. Kesemuanya merupakan keseluruhan rangkaian alur kerja (business of process) Rudenim dalam melaksanakan tugas fungsi pengelolaan dan pengawasan keimigrasian oleh Rudenim terhadap pengungsi dan pencari suaka. Tidak hanya itu saja, SOP dimaksud dapat menjadi tolak ukur untuk merencanakan berapa besar kebutuhan anggaran minimal yang harus tersedia serta berapa jumlah petugas yang dibutuhkan secara proporsional, termasuk anggaran pengadaan infrastruktur.

Berdasarkan hal-hal yang telah dikemukakan dapat terlihat jelas bahwa terdapat perbedaan ,mengenai pelaksanaan tugas rudenim sebelum dan sesudah adanya Peraturan Presiden Nomor 125 tahun 2016 dilihat dari aspek kelembagaan dan ketatalaksanaan, infrastruktur dan perencanaan. Dalam hal ini masih terdapat perbedaan lainnya dalam pelaksanaan tugas Rudem, diantaranya adalah terlihat pada prosedur yang dilakukan dalam penanganannya. Sebelum diberlakukannya Peraturan Presiden Nomor 125 Tahun 2016, saat seseorang yang mengaku dirinya sebagai pengungsi maupun pencari suaka dan ditemukan tidak memiliki dokumen, maka aparat setempat seperti Kepolisian, Angkatan Laut dan sebagainya, akan melaporkannya kepada Kantor Imigrasi Kelas I Makassar perihal hal tersebut. Akan tetapi sejak di berlakukannya Peraturan Presiden tersebut, bila ditemukan adanya pengungsi ataupun pencari suaka, maka akan langsung ditangani oleh pihak Rudenim Makassar. Walaupun demikian, selama ini belum dilakukan pengawasan saat ditemukan ${ }^{28}$

Seseorang yang mengaku dirinya pencari suaka dan pengungsi akan mengalami proses yang panjang dalam pengajuan permohonan sebagai pengungsi oleh UNHCR. Dalam hal ini para pemohon akan diperiksa identitasnya oleh UNHCR dan akan diproses lebih lanjut sampai diputuskan bahwa pemohon mendapatkan status pengungsi oleh UNHCR tersebut. Bagi pengungsi yang memiliki keluarga akan ditempatkan ditempat-tempat penampungan yang didanai oleh IOM, sedangkan bagi pria yang masih lajang, sementara masih ditempatkan di Rudenim sambil menunggu tempat penampungan yang tersedia. Akan tetapi tidak semua permohonan dapat dikabulkan oleh UNHCR, sehingga di Rudenim Makassar mengalami overkapasitas, yang seharusnya menampung 80 orang, ternyata kapasitas yang ada mencapai 135 orang yang terdiri dari deteni pelanggar keimigrasian, pengungsi dan pencari suaka. ${ }^{29} \mathrm{Hal}$ yang berbeda dapat terlihat pada orang-orang yang memiliki status pengungsi dan ditempatkan dirumah penampungan, yang beberapa diantaranya menyerupai hotel, sehingga kehidupan para pengungsi pun terasa lebih nyaman dibandingkan pengungsi masih ditempatkan di Rudenim. Oleh karena itu untuk mencegah timbulnya kecemburuan sosial, maka pihak Rudenim pun memiliki berbagai rencana pengembangan untuk meningkatkan sarana

28. Wawancara dengan Kasi Regminlap pada tanggal 7 September 2017

29. Wawancara dengan Kepala Rudenim Makassar. Tanggal 6 September 2017 
dan prasarana yang ada di lingkungan Rudenim Makassar.

Para pengungsi, khususnya yang berada di tempat penampungan harus mematuhi berbagai tata tertib yang diberlakukan yaitu mereka dilarang untuk mengendarai kendaraan bermotor, seperti motor ataupun mobil mengingat mereka tidak memiliki identitas yang sah untuk pembuatan SIM di Indonesia. Kendaraan yang hanya diperbolehkan bagi mereka adalah sepeda. Selain itu juga terdapat waktu-waktu mereka untuk keluar dari tempat penampungan yaitu antara pukul 09.00 WIT sampai pukul 20.00 WIT. Dalam hal ini pihak Rudenim secara teratur melakukan pengawasan melalui para pengelola dan petugas keamanan tempat penampungan untuk memantau keberadaan para pengungsi ditempat penampungan. Bila terdapat pengungsi yang tidak berada ditempat pada waktu-waktu yang telah ditentukan, pihak Rudenim akan langsung mengetahui dan mencari informasi akan keberadaan pengungsi tersebut. $\mathrm{Hal}$ ini untuk menghindari kasus yang pernah terjadi yaitu pengungsi yang tidak berada ditempat selama hampir satu bulan. Setelah dilakukan pemeriksaan, ternyata pengungsi tersebut telah berada di Jakarta bersama saudaranya. la melaporkan keberadaanya tersebut di Jakarta. Dengan kejadian tersebut, pihak Imigrasi berkoordinasi dengan IOM untuk tidak lagi mendanai kehidupannya di Makassar, baik berupa tempat tinggal maupun kebutuhan makan sehari-hari, sehingga tempat yang kosong dapat ditempati orang lain. Dengan perginya pengungsi tersebut ke Jakarta, maka secara otomatis ia telah dikembalikan tempatnya ke Jakarta dan tidak dapat kembali ke tempat penampungan di Makassar walaupun ia mengajukan permohonan maaf atas kesalahannya tersebut. ${ }^{30}$
Hal tersebut merupakan salah satu sanksi yang diterapkan oleh pihak Rudenim Makassar terhadap pelanggaran yang dilakukan oleh pengungsi. Sanksi juga akan diberikan kepada pengungsi yang berkonflik dengan pengungsi lainnya, sehingga bila tidak ada kata damai, maka mereka akan dimasukkan ke dalam Rudenim Makassar selama 14 (empat belas) hari untuk menimbulkan efek jera. Bila tingkah laku pengungsi yang berkonflik tersebut dianggap baik, maka akan dikeluarkan dari Rudenim dan dikembalikan ke tempat penampungan. ${ }^{31}$

Selain tata tertib yang harus dipatuhi, para pengungsi juga memiliki berbagai kewajiban yang harus dipenuhi, yang salah satunya adalah mereka harus melaporkan diri setiap bulan agar pihak Rudenim dapat mengetahui bahwa para pengungsi masih ada pada tempat tersebut. Pada saat pengungsi melaporkan diri, mereka akan mendapatkan stempel pada kartu identitas yang disediakan oleh pihak Rudenim Makassar. Bagi Pengungsi yang tidak melaporkan diri selama 3 (tiga) kali berturut-turut tanpa alasan yang dapat diterima, ditempatkan di Rumah Detensi Imigrasi, sebagaimana diamanatkan dalam Pasal 36 Peraturan Presiden Nomor 125 Tahun 2016 tentang Penanganan Pengungsi dari Luar Negeri.

Pemberlakuan wajib lapor sebulan sekali bagi para pengungsi, ternyata menimbulkan permasalahan bagi para pengungsi. $\mathrm{Hal}$ ini dikarenakan aturan tersebut dianggap memberatkan para pengungsi karena lokasi Rudenim Makassar yang berada di luar kota Makassar, terlebih bila harus membawa serta seluruh keluarga. Mereka merasa bingung akan transportasi yang dapat digunakan dan merasa keberatan bila harus mengeluarkan uang dari dana yang diberikan IOM tersebut. ${ }^{32}$

30. Wawancara dengan Kepala Rudenim Makassar tanggal 6 September 2017

31. Wawancara dengan Kasi Regminlap pada tanggal 7 Septrember 2017

32. Wawancara dengan pengungsi di tempat penampungan Wisma MSM dan Wisma D'Khanza tanggal 6 September 2017 
Berbagai persoalan yang terjadi ditempat penampungan tidak menurunkan kinerja pihak Rudenim dalam melakukan pengawasan yang sudah menjadi tanggung jawab mereka untuk melaksanakannya. Oleh karena itu dalam melakukan pengawasan pengiriman ke negara tujuan bagi pengungsi dan perpindahan pengungsi ke propinsi lain juga tidak mendapatkan permasalahan berarti. Hal ini dikarenakan untuk proses pengiriman ke negara tujuan, pengawasannya memang dilakukan oleh pihak rudenim, terutama berkaitan dengan pengawalan keberangkatan dan penyelesaian dokumen yang dibutuhkan seperti Passpor, Visa dan sebagainya. Sedangkan Pengawasan dalam rangka pemindahan pengungsi ke provinsi lain dilakukan dengan cara memindahkan pengungsi dari tempat penampungan ke Rudenim Makassar terlebih dahulu sebelum yang bersangkutan dipindahkan ke provinsi lain. Hal ini untuk mencegah pengungsi melarikan diri dari upaya pemidahan tersebut. ${ }^{33}$

Berkenaan dengan hal tersebut, penanganan pengungsi memang perlu menjadi perhatian berbagai pihak, mengingat pengungsi bukan hanya tugas Rudenim Makassar untuk penanganannya bila merujuk pada Peraturan Presiden Nomor 125 Tahun 2016 tentang Penanganan Pengungsi dari Luar Negeri.

\section{PENUTUP}

\section{Kesimpulan}

Berdasarkan hasil penelitian dan analisis yang telah disampaikan sebelumnya dapat disimpulkan bahwa Rudenim Makassar telah berupaya melakukan penanganan pengungsi dari luar negeri sesuai dengan Peraturan Presiden No.125 Tahun 2016 tentang Penanganan Pengungsi dari Luar
Negeri. Akan tetapi bila dilihat dari aspek kelembagaan dan ketatalaksanaan serta infrastruktur, maka tiga hal tersebut belum sesuai dengan postur tugas dan kewenangan Rudenim berdasarkan Peraturan Presiden Nomor 125 Tahun 2016 tentang Penanganan Pengungsi dari Luar Negeri.

Hal ini dapat terlihat aspek kelembagaan dan ketatalaksanaan yang belum mengalami perubahan struktur organisasi setelah adanya Peraturan Presiden Nomor 125 Tahun 2016 tentang Penanganan Pengungsi dari Luar Negeri walaupun telah terjadi pelimpahan kewenangan pengawasan dari Kantor Imigrasi Kelas I Makasar kepada Rumah Detensi Imigrasi Makasar. Hal ini menjadi salah satu permasalahan karena secara kelembagaan dan ketatalaksanaan, standar operasional prosedur (SOP) yang digunakan masih mengacu pada Peraturan Direktur Jenderal Imigrasi Nomor IMI.1917OT.02.01 Tahun 2013 Tentang Standar Operasional Prosedur (SOP) Rumah Detensi Imigrasi yang sudah tidak sesuai dengan Peraturan Presiden Nomor 125 Tahun 2016. Selain itu juga Rudenim Makassar memiliki keterbatasan sumber daya manusia yaitu sebanyak 27 orang saja dan tidak sebanding dengan pelaksanaan tugas yang dilakukan walaupun terdapat penambahan 11 (sebelas) tenaga honorer dalam membantu penjagaan keamanan di Rudenim Makassar pada malam hari

Dilihat dari aspek infrastruktur, perangkat mobilisasi yang digunakan saat ini di Rudenim Makassar masih sangat terbatas yaitu hanya tersedia 1 (satu) mobil dinas yang digunakan untuk melakukan pengawasan di berbagai tempat penampungan yang letaknya sangat jauh. Selain itu juga keterbatasan perangkat keamanan dalam melakukan pengawasan menyebabkan perangkat keamanan tersebut hanya diperuntukkan bagi penjaga keamanan

33. Wawancara dengan Kasi Regminlap pada tanggal 7 September 2017 
di Rudenim Makassar saja. Dalam hal ini pengawasan pengungsi di Rudenim masih belum maksimal karena belum tersedianya sarana dan parasarana seperti rumah ibadah, lapangan olahraga dan pagar pembatas untuk mensterilkan area tertentu, sehingga harus membuka pintu pagar bila terdapat aktivitas olahraga atau keagamaan yang sangan rentan terhadap upaya melarikan diri para pengungsi dan pencari suaka.

Kemudian pada aspek perencanaan, Rudenim belum memiliki konsep perencanaan dalam hal menyesuaikan kelembagaan dan ketatalaksanaan pada Rudenim serta perencanaan dalam penyediaan infrastruktur yang mendukung pelaksanaan tugas.

\section{Saran}

Berdasarkansimpulanyangdisampaikan, maka penelitian ini merekomendasikan kepada Direktur Jenderal imigrasi u.p. Direktur Pengawasan dan Penindakan Keimigrasian yang struktural membawahi Kepala Rumah Detensi Imigrasi (Rudenim):

1. Secara Kelembagaan, perlu dilakukan penyesuaian terhadap struktur kelembagaan yang ada pada Rudenim, dalam hal ini yang lebih spesifik adalah menambah struktur tugas baru serta menyediakan sumber daya manusia (SDM) guna melaksanakan tugas pengawasan keimigrasian;

2. Perlu melakukan revisi terhadap Peraturan Direktur Jenderal Imigrasi No.I MI.1917-OT.02.01 Tahun 2013 tentang Standar Operasional Prosedur Rumah Detensi Imigrasi sehubungan dengan diberlakukannya Peraturan Presiden No.125 Tahun 2016 tentang Penanganan Pengungsi dari Luar Negeri.

3. Menyediakan infrastruktur yang mendukung tugas Rudenim dalam melaksanakan tugas pengawasan keimigrasian.

4. Perlu adanya Unit Layanan Pengungsi di Makassar sebagai perpanjangan tangan
Rudenim dalam melakukan pengawasan mengingat lokasi Rudenim yang berada sangat jauh dari ibukota provinsi sehingga membutuhkan waktu yang cukup lama bila ada panggilan darurat. 


\section{DAFTAR PUSTAKA}

\section{Buku:}

Balitbang HAM, Buku Pedoman HAM bagi Petugas Rumah Detensi Imigrasi, Jakarta: Balitbang HAM Kemenkumham, 2011.

Betts, Alexander and Loescher, Gil (Ed.), Refugee in International Relation, New York: Oxford University Press, 2011.

Bungin, H.M. Burhan, Metodologi Penelitian Kuantitatif (Komunikasi, Ekonomi, dan Kebijakan Publik Serta IImu-IImu Sosial Lainnya, Jakarta: Kencana, 2017

Missbach, Antje, Troubled Transit : Politik Indonesia Bagi Para Pencari Suaka, penerjemah: Mayolisia Ekayanti, Edisi pertrama, Jakarta, Yayasan Pustaka Obor Indonesia, 2016

Sakharina, lin Karita Sakharina dan Kadarudin, Pengantar Hukum Pengungsi Internasional (Perbedaan istilah Pencari Suaka, Pengungsi Internasional dan Pengungsi dalam Negeri, Yogyakarta: Deepublish, 2017

Swansburg, R.C.\& Swansburg, R.J.. Introductory management \& leadership. (second edition), Boston: Jones \& Bartlett Publishers, 1999

University of Pune, "Human Rights Vulnerable and Disadvantaged Groups" (Course Book-II), University of Pune Press, Pune, 2012

Valley, Paul (ed.), Cita Masyarakat Abad 21: Visi Gereja tentang Masa Depan, Kanisius, Yogyakarta, 2007

\section{Jurnal/Makalah/Artikel/Prosiding:}

Afriandi, Fadli dan Nizmi, Yusnarida Eka, Kepentingan Indonesia Belum Meratifikasi Konvensi 1951 Dan Protokol 1967 Mengenai Pengungsi Internasional Dan Pencari Suaka, Transnasional: Jurnal IImu Hubungan Internasional Universitas Riau Vol 5 No. 2 Tahun 2014

\section{Peraturan Perundang-Undangan:}

Republik Indonesia, Undang-Undang Nomor 37 Tahun 1999 tentang Hubungan Luar Negeri

Republik Indonesia, Undang-Undang Nomor 6 Tahun 2011 Tentang Keimigrasian

Republik Indonesia, Peraturan Presiden Nomor 125 Tahun 2016 tentang Penanganan Pengungsi dari Luar Negeri (PPLN)

Peraturan Direktur Jenderal Imigrasi Nomor IMI.1917-OT.02.01 Tahun 2013 Tentang Standar Operasional Prosedur (SOP) Rumah Detensi Imigrasi

\section{Sumber Lain}

Right Now 15 April 2014, (http://rightnow.org.au/ opinion-3/the-human-face-of-refugeepolicy/)

DetikNews 9 Maret 2017, ( https://news.detik. com/ berita/d-3442963/14425-imigranilegal-penuhi-indonesia-ini-langkahpemerintah)

Suaka, diakses pada 5 Juni 2017 (https:// suaka.or.id/public-awareness/idmasalah-perlindungan/ pada 5 Juni 2017)

NHCR Indonesia, diakses pada 10 Juni 2017 (http://www.unhcr.org/id/pengungsi) 